\title{
Przewlekłe zakrzepowo-zatorowe nadciśnienie płucne - diagnostyka i nowe możliwości terapii farmakologicznej w świetle wytycznych ESC/ERS 2015
}

\section{Chronic thromboembolic pulmonary hypertension - diagnosis and novel therapeutic options according to ESC/ERS 2015 guidelines}

\author{
Remigiusz Kazimierczyk ${ }^{1}$, Karol A. Kamiński ${ }^{2,3}$ \\ ${ }^{1}$ Klinika Kardiologii Uniwersytetu Medycznego w Białymstoku \\ ${ }^{2}$ Klinika Kardiologii Uniwersyteckiego Szpitala Klinicznego w Białymstoku \\ ${ }^{3}$ Zakład Medycyny Populacyjnej i Prewencji Chorób Cywilizacyjnych Uniwersytetu Medycznego w Białymstoku
}

\section{Streszczenie}

Przewlekłe zakrzepowo-zatorowe nadciśnienie płucne (CTEPH) to poważne schorzenie, najczęściej wywołane niepełną rekanalizacją naczyń płucnych po przebytej ostrej zatorowości płucnej prowadzącą do znacznej przebudowy pozostałego łożyska płucnego i w efekcie - do niewydolności prawokomorowej serca. Rokowanie zależy od szybkiego rozpoznania CTEPH i odpowiedniego leczenia. Mimo dostępności skutecznej metody, tj. endarterektomii płucnej (PEA), ponad $1 / 3$ chorych nie kwalifikuje się do tego typu operacji ze względu na lokalizację i charakter zmian. W ich przypadku, oraz przy przetrwałym CTEPH po PEA, należałoby zastosować leczenie swoiste riociguatem. U pewnej grupy pacjentów można rozważyć nowoczesną metodę balonowej angioplastyki tętnic płucnych.

Słowa kluczowe: przewlekłe zakrzepowo-zatorowe nadciśnienie płucne, niewydolność prawej komory, endarterektomia płucna, angioplastyka balonowa tętnic płucnych, riociguat

Folia Cardiologica 2016; 11, 5: 394-400

\section{Wstęp}

Przewlekłe zakrzepowo-zatorowe nadciśnienie płucne (CTEPH, chronic thromboembolic pulmonary hypertension) jest jednym z głównych typów przedwłośniczkowego nadciśnienia płucnego ( $\mathrm{PH}$, pulmonary hypertension), które definiuje się jako średnie ciśnienie w tętnicy płucnej (mPAP, mean pulmonary arterial pressure) większe lub równe $25 \mathrm{~mm}$ Hg przy prawidłowym ciśnieniu zaklinowania w tętnicy płucnej w pomiarze bezpośrednim podczas cewnikowania prawego serca [1]. Do rozpoznania CTEPH niezbędne jest również potwierdzenie obecności materiału zakrzepowo-zatorowego w tętnicach płucnych, mimo trwają- cego co najmniej 3 miesiące leczenia przeciwzakrzepowego. Przyjmuje się, że pierwotnym elementem patogenetycznym CTEPH jest zatorowość płucna (PE, pulmonary embolism), po której nie nastąpiła pełna rekanalizacja łożyska płucnego pod wpływem endogennego układu fibrynolitycznego $[2,3]$. Często dochodzi również do trwałej obturacji małych, subsegmentarnych naczyń. Przewlekłe zmiany zakrzepowe ulegają zwłóknieniu, powstają liczne przegrody łącznotkankowe, opisywane w badaniach obrazowych jako sieci lub przepony upośledzające przepływ w tętnicach płucnych. Należy jednak podkreślić, że wcześniejsze wystąpienie PE nie jest niezbędne do rozpoznania CTEPH. Zwiększony opór naczyniowy w części łożyska płucnego wywołany obecnością

Adres do korespondencji: prof. dr hab. n. med. Karol Adam Kamiński, Klinika Kardiologii, Uniwersytecki Szpital Kliniczny, ul. Skłodowskiej-Curie 24A, 15-276 Białystok, tel. 857468 656, faks 857468 604, e-mail: fizklin@gmail.com 


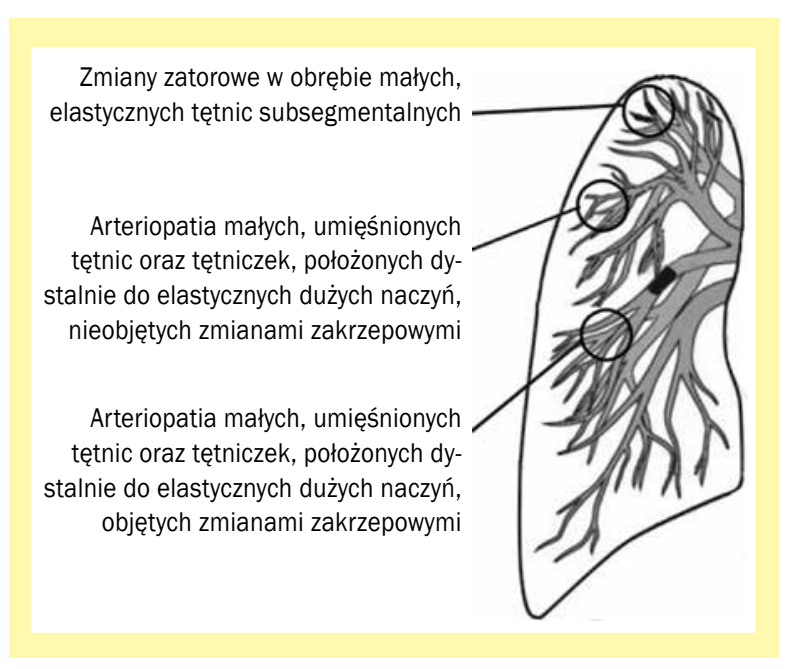

Rycina 1. Składowe choroby małych naczyń w przewlekłym zakrzepowo-zatorowym nadciśnieniu płucnym (obraz płuc wg „Anatomy \& Physiology", www.en.wikipedia.org)

przetrwałej skrzepliny powoduje wzrost przepływu przez drożne naczynia i prowadzi do ich przebudowy (ryc. 1) [4]. Przyczynia się to do dalszego zwiększenia naczyniowego oporu płucnego, rozwoju PH, a w konsekwencji - niewydolności prawokomorowej serca i przedwczesnego zgonu [2-5].

Choroba stanowi duży problem diagnostyczny. Obecnie badanie przesiewowe po ostrej PE nie jest zalecane u pacjentów bez objawów ze względu na małą częstość rozwoju CTEPH (średnio ok. 3,8\%) [1, 3]. Natomiast pojawienie się takich objawów, jak ograniczenie tolerancji wysiłku czy duszność, powinno być impulsem do rozpoczęcia diagnostyki w kierunku CTEPH. Pewnym problemem w diagnostyce jest powszechnie obserwowany okres znaczącej klinicznej poprawy po epizodzie zatorowości, trwający zazwyczaj 6-24 miesięcy (honeymoon period). Po takim czasie pacjenci często nie zwracają uwagi na możliwy związek przyczynowy z PE, co opóźnia diagnostykę CTEPH. Jednakże większość chorych, u których diagnozuje się CTEPH, nie zgłasza objawowego epizodu PE w przeszłości, natomiast może podawać wywiad zakrzepicy żylnej. Brak wywiadu epizodu żylnej choroby zakrzepowo-zatorowej (VTE, venous thromboembolism) również nie wyklucza rozpoznania CTEPH ze względu na możliwość jej subklinicznego przebiegu lub występowania zakrzepicy in situ [6]. Nie ulega wątpliwości, że należy pogłębiać wiedzę zarówno lekarzy, jak i pacjentów dotyczącą ryzyka CTEPH po ostrej PE oraz o dostępności w Polsce metod leczenia operacyjnego i farmakologicznego, znacząco poprawiających rokowanie.

\section{Diagnostyka}

Wczesne postawienie diagnozy CTEPH jest niezwykle trudne z powodu występowania okresu bezobjawowego w historii naturalnej choroby oraz mało swoistych objawów.
Tabela 1. Skala ryzyka rozwoju przewlekłego zakrzepowo-zatorowego nadciśnienia płucnego (CTEPH, chronic thromboembolic pulmonary hypertension) (wg [12])

\begin{tabular}{lc} 
Czynnik ryzyka & Punkty \\
Nieprowokowana PE & +6 \\
Niedoczynność tarczycy & +3 \\
$\begin{array}{l}\text { Pojawienie się objawów > 2 tygodnie } \\
\text { wcześniej niż rozpoznanie PE }\end{array}$ & +3 \\
$\begin{array}{l}\text { Dysfunkcja prawej komory w CT } \\
\text { lub echokardiografii }\end{array}$ & +2 \\
Rozpoznana cukrzyca & \\
Leczenie trombolityczne lub embolektomia & -2 \\
Interpretacja & -2 \\
Niskie ryzyko CTEPH & Suma punktów \\
Wysokie ryzyko CTEPH & $\leq 6$ \\
\hline
\end{tabular}

$\mathrm{PE}$ (pulmonary embolism) - zatorowość płucna; CT (computed tomography) - tomografia komputerowa

Przeciętny czas między wystąpieniem pierwszych objawów CTEPH a diagnostyką w wyspecjalizowanym ośrodku wynosi średnio 2,7 roku [7]. Ponadto symptomy obserwuje się stosunkowo późno w czasie naturalnego przebiegu choroby. Duszność czy zmniejszona tolerancja wysiłku może się pojawić dopiero wtedy, gdy 40\% łożyska płucnego ulegnie obturacji lub arteriopatii $[5,6,8]$. Bardzo często objawy kliniczne przypominają kolejny ostry epizod PE lub tętnicze nadciśnienie płucne (PAH, pulmonary arterial hypertension) [9]. Choroba jest ściśle związana z przebytą VTE, choć u mniej niż 75\% chorych stwierdza się dodatni wywiad w jej kierunku [10], a etiologia choroby u osób bez wywiadu PE pozostaje niepewna [2, 6, 9]. Wykazano, że proliferacja błony wewnętrznej i tworzenie zmian splotowatych w dystalnych naczyniach płucnych są zbliżone histopatologicznie do występujących u osób chorujących na $\mathrm{PAH}[8,11]$. Autorzy innej teorii sugerują istnienie zjawiska nazywanego zakrzepicą in situ, która rozwija się w tętnicach płucnych jako skutek zwiększonej ekspresji czynnika VIII krzepnięcia i inhibitora aktywatora plazminogenu I [8, 11].

Jest kilka zaproponowanych skal prawdopodobieństwa wystąpienia CTEPH po epizodzie PE (tab. 1) [12-15]. We wszystkich głównym czynnikiem ryzyka jest przebyta PE (szczególnie idiopatyczna). Podwyższone ryzyko dotyczy również osób młodszych i z dużym ubytkiem perfuzji w scyntygrafii wentylacyjno-perfuzyjnej. Istotną wartość predykcyjną CTEPH ma też wysokie ciśnienie skurczowe w tętnicy płucnej (> $50 \mathrm{~mm} \mathrm{Hg}$ ) stwierdzone echokardiograficznie podczas epizodu PE [16].

Głównym badaniem przesiewowym u pacjentów, u których podejrzewa się CTEPH, jest badanie echokardiograficzne serca (tab. 2) [1]. Stwierdzenie wysokiego echokardiograficznego prawdopodobieństwa PH upoważnia do dalszej diagnostyki, w tym cewnikowania prawego 
Tabela 2. Echokardiograficzne prawdopodobieństwo nadciśnienia płucnego (PH, pulmonary hypertension) (wg [1], zmodyfikowano)

\begin{tabular}{|c|c|c|}
\hline $\begin{array}{l}\text { Prędkość maksymalna } \\
\text { niedomykalności trójdzielnej [m/s] }\end{array}$ & $\begin{array}{c}\text { Obecność innych „wskaźników” * PH } \\
\text { w echo }\end{array}$ & $\begin{array}{l}\text { Prawdopodobieństwo PH } \\
\text { w echo }\end{array}$ \\
\hline$\leq 2,8$ lub nie do oceny & $\mathrm{Nie}$ & Niskie \\
\hline$\leq 2,8$ lub nie do oceny & Tak & Średnie \\
\hline $2,9-3,4$ & $\mathrm{Nie}$ & \\
\hline $2,9-3,4$ & Tak & Wysokie \\
\hline$>3,4$ & Niewymagana & \\
\hline \multicolumn{3}{|c|}{$\begin{array}{l}\text { *Inne „wskaźniki” PH w echo - powinny być obecne przynajmniej } 2 \text { echokardiograficzne wskaźniki w } 2 \text { różnych kategoriach (A/B/C) } \\
\text { aby zmienić poziom echokardiograficznego prawdopodobieństwa PH }\end{array}$} \\
\hline Kategoria A-komory & Kategoria B - tętnica płucna & Kategoria C - VCI i RA \\
\hline $\begin{array}{l}\text { Stosunek wymiaru RV do LV u ich podsta- } \\
\text { wy > 1,0 } \\
\text { Spłaszczenie przegrody międzykomoro- } \\
\text { wej (wskaźnik ekscentryczności LV > 1,1 } \\
\text { w skurczu i/lub rozkurczu) }\end{array}$ & $\begin{array}{l}\text { Czas akceleracji krzywej wyrzutu z RV } \\
<105 \mathrm{~ms} \text { i/lub śródskurczowe zwolnienie } \\
\text { przepływu } \\
\text { Wczesnoskurczowa prędkość niedomykal- } \\
\text { ności płucnej > 2,2 m/s } \\
\text { Szerokość tętnicy płucnej > } 25 \text { mm }\end{array}$ & $\begin{array}{l}\text { Szerokość VCI > } 21 \text { mm ze zmniejszoną } \\
\text { amplitudą oddechową (<50\% podczas } \\
\text { szybkich wdechów nosem lub < } 20 \% \text { pod- } \\
\text { czas spokojnego oddychania) } \\
\text { Pole powierzchni RA (w okresie końcowo- } \\
\text { skurczowym) > } 18 \mathrm{~cm}^{2}\end{array}$ \\
\hline
\end{tabular}

serca. Echokardiograficzne pośrednie i niskie ryzyko $\mathrm{PH}$, w zależności od współistnienia czynników ryzyka lub chorób współistniejących, wiąże się z koniecznością dalszej obserwacji echokardiograficznej albo rozważeniem innego rozpoznania [1]. Scyntygrafia wentylacyjno-perfuzyjna charakteryzuje się obecnie największą czułością i swoistością w rozpoznaniu CTEPH. Co najmniej jedno (segmentowe) zaburzenie perfuzji wykryte podczas scyntygrafii płuc wskazuje na duże prawdopodobieństwo choroby. Pacjent powinien być wówczas skierowany do ośrodka referencyjnego leczenia PH w celu wykonania cewnikowania prawego serca (ryc. 2) [1]. Zabieg z wykorzystaniem cewnika Swana-Ganza umożliwia bezpośredni pomiar ciśnienia w tętnicy płucnej (PAP, pulmonary arterial pressure) oraz pozwala wykluczyć PH wtórne do chorób lewego serca. Dokładny bezpośredni pomiar mPAP jest szczególnie ważny ze względu na znaczenie rokownicze i możliwość kwalifikacji do terapii - zarówno chirurgicznej, jak i farmakologicznej - a należy pamiętać, że wyliczenia oparte na wzorach wyprowadzających średnie ciśnienie płucne z prędkości fali zwrotnej trójdzielnej ocenianej w badaniu echokardiograficznym często zawyżają te wartości. Segmentarne ubytki perfuzji w scyntygrafii wraz z potwierdzonym podczas cewnikowania prawego serca przedkapilarnym PH (mPAP $\geq 25 \mathrm{~mm} \mathrm{Hg}$ z ciśnieniem zaklinowania w tętnicy płucnej $\leq 15 \mathrm{~mm} \mathrm{Hg}$ ) potwierdzają rozpoznanie (ryc. 2). W trakcie kwalifikacji do leczenia operacyjnego niezbędne jest również potwierdzenie lokalizacji zmian i możliwości ich usunięcia zabiegowego w dodatkowych badań obrazowych, takich jak arteriografia tętnic płucnych czy angiografia płucna tomografii komputerowej. Uznaje się, że rozpoznania CTEPH można dokonać po co najmniej 3 miesiącach skutecznego leczenia przeciwzakrzepowego (w celu odróżnienia CTEPH od podostrego epizodu PE) [1].

\section{Leczenie}

Wszyscy chorzy z CTEPH powinni otrzymywać przewlekłą antykoagulację do końca życia (również po skutecznej endarterektomii płucnej [PEA, pulmonary endarterectomy]), by zapobiec zarówno nawrotom VTE, jak i tworzeniu się zakrzepów in situ w tętnicach płucnych. Na leczenie farmakologiczne dodatkowo składa się stosowanie leków moczopędnych i tlenu w przypadku występowania niewydolności prawokomorowej i hipoksemii [1].

Przewlekłe zakrzepowo-zatorowe nadciśnienie płucne to jedyny rodzaj PH, które można całkowicie wyleczyć [17]. Taka możliwość istnieje dzięki zapoczątkowanym w drugiej połowie XX wieku zabiegom PEA, które obecnie stanowią leczenie z wyboru u pacjentów z rozpoznanym proksymalnym CTEPH (typu 1 lub 2 wg Jamiesona) [17-19]. Celem PEA jest mechaniczne usunięcie mas zawężających proksymalne naczynia płucne wraz ze skrzeplinami i błoną wewnętrzną. Warunkiem wykonania zabiegu jest tak zwana dostępność chirurgiczna zmian. Zarówno operacja, jak i przebieg pooperacyjny wymagają dużej biegłości i doświadczenia w tego typu zabiegach. W trakcie operacji wykorzystuje się krążenie pozaustrojowe, jednak ze względu na konieczność krótkotrwałego całkowitego zatrzymania krążenia procedura jest przeprowadzana w głębokiej hipotermi. Mimo ryzyka operacji skuteczna PEA może się przełożyć na znaczną poprawę stanu klinicznego pacjenta i jego rokowania. W ostatnich doniesieniach potwierdzono, że rokowanie długoterminowe u operowanych pacjentów 


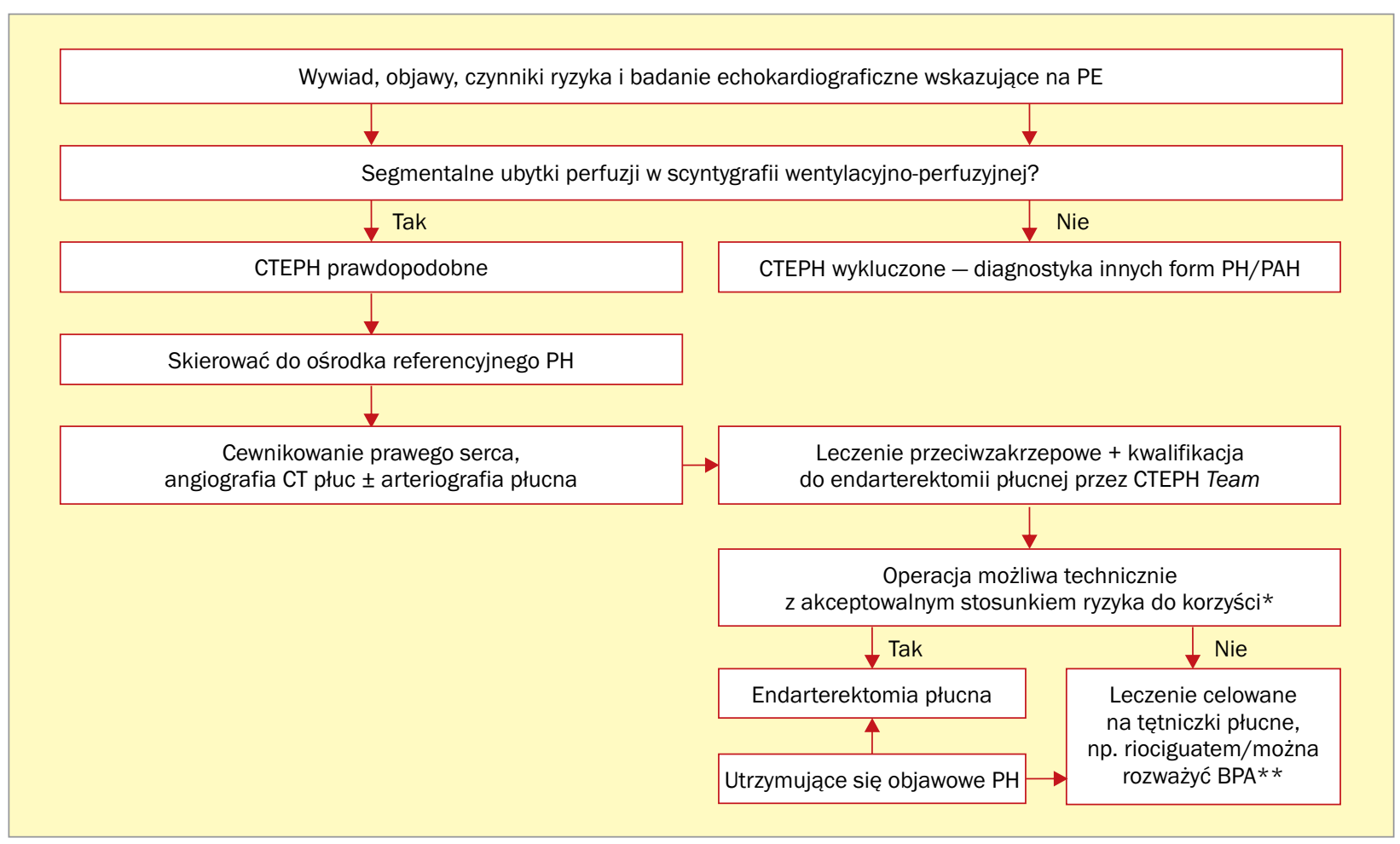

Rycina 2. Algorytm diagnostyczno-terapeutyczny dotyczący przewlekłego zakrzepowo-zatorowego nadciśnienia płucnego (CTEPH, chronic thromboembolic pulmonary hypertension) (wg [1], zmodyfikowano); *U pacjentów, u których operacja jest możliwa technicznie, ale cechuje ich zbyt wysoki stosunek ryzyka do korzyści, można rozważyć wykonanie BPA; **w niektórych ośrodkach terapię farmakologiczną i BPA rozpoczyna się jednocześnie; PH (pulmonary hypertension) - nadciśnienie płucne; PAH (pulmonary arterial hypertension) - tętnicze nadciśnienie płucne; CT (computed tomography) - tomografia komputerowa; BPA (balloon pulmonary angioplasty) - angioplastyka balonowa tętnic płucnych

jest lepsze niż u pacjentów nieoperowanych, mimo podobnego profilu hemodynamicznego przy rozpoznaniu [20].

Decyzja o kwalifikacji do zabiegu musi być podjęta przez doświadczony zespół złożony z kardiochirurga, kardiologa i kardiologa interwencyjnego. Zespół ten, tak zwany CTEPH Team, podejmując decyzję o PEA, bierze pod uwagę nie tylko operacyjność zmian, ale również wiele czynników dodatkowych, takich jak choroby współistniejące, parametry hemodynamiczne czy zgoda pacjenta na leczenie kardiochirurgiczne. Obecnie wiek pacjenta nie stanowi bezwzględnego przeciwwskazania do operacji. Mimo to aż 40\% pacjentów z CTEPH nie kwalifikuje się do PEA [10].

W przypadku nieskutecznej PEA, tj. wtedy gdy podwyższone PAP nie ustępuje po co najmniej 6 miesiącach od operacji, należy rozpoznać przetrwałe/nawrotowe CTEPH. Dotyczy to nawet $1 / 3$ osób po PEA [20].

\section{Farmakologiczne leczenie przyczynowe}

Chociaż wyjściowym elementem patofizjologii CTEPH jest epizod zakrzepowo-zatorowy, to - ze względu na organizację skrzeplin, ich włóknienie oraz rozplem fibroblastów błony wewnętrznej - leczenie przeciwzakrzepowe nie jest w stanie usunąć obturacji i obniżyć PAP do wartości prawidłowych. Mimo to każdy pacjent z CTEPH powinien zostać poddany takiemu leczeniu w celu zapobieżenia kolejnym epizodom choroby zakrzepowo-zatorowej, a także wykrzepianiu krwi w tętnicach płucnych, w których pojawiają się obszary o zwolnionym przepływie.

Należy pamiętać, że u pacjentów, u których nie ma możliwości chirurgicznego usunięcia zmian, patogeneza CTEPH może być nieco odmienna. W tej grupie chorych dominuje nie tyle fizyczne utrudnienie przepływu przez duże naczynia, co przebudowa ściany drobnych naczyń, nieco zbliżona do obrazu obserwowanego w PAH. Z tego względu z udziałem grupy chorych zdyskwalifikowanych z zabiegu PEA, lub u których PH utrzymywało się mimo przeprowadzonego zabiegu PEA, przeprowadzono badania nad lekami o działaniu wazodylatacyjnym i antyproliferacyjnym. Mimo obiecujących wstępnych wyników badań z zastosowaniem sildenafilu, bosentanu i treprostinilu nie uzyskano jednoznacznego potwierdzenia skuteczności w dużym badaniu randomizowanym [20-25]. W związku z tym można rozważyć stosowanie tych leków tylko 
w przypadku braku innych możliwości terapeutycznych (zalecenie IIb) [1]. Obecnie jedynym lekiem o działaniu wazodylatacyjnym i antyproliferacyjnym, jednoznacznie zalecanym w wytycznych, którego skuteczność leczenia pacjentów z CTEPH wykazano w dużym badaniu randomizowanym, pozostaje riociguat $[1,24]$. Riociguat jest stymulatorem rozpuszczalnej cyklazy guanylanowej (sGC, soluble guanylate cyclase), która, wiążąc się z tlenkiem azotu, katalizuje synteze cyklicznego guanozynomonofosforanu (cGMP, cyclic guanosine monophosphate) i wywiera działanie wazodylatacyjne, przeciwzapalne i antyprofliferacyjne. Przekłada się to na znaczną poprawę naczyniowej hemodynamiki płucnej i zwiększenie wydolności wysiłkowej [26].

Podstawą rejestracji riociguatu było badanie CHEST-1 (Chronic Thromboembolic Pulmonary Hypertension Soluble Guanylate Cyclase Stimulator Trial 1) przeprowadzone u 261 pacjentów z nieoperowalnym lub przetrwałym/ /nawrotowym CTEPH [24]. Grupa pacjentów przyjmujących riociguat po 16 tygodniach terapii charakteryzowała się istotnie statystycznie dłuższym dystansem (o 46 m) w teście 6-minutowego marszu (6MWT, 6-minute walk test) niż grupa przyjmująca placebo. W badaniu obserwowano jednoznaczny korzystny wpływ na drugorzędowe punkty końcowe, takie jak zmniejszenie naczyniowego oporu płucnego, obniżenie stężenia N-końcowego propeptydu natriuretycznego typu B (NT-proBNP, N-terminal pro-B-type natriuretic peptide) czy zmiana klasy czynnościowej według Światowej Organizacji Zdrowia (WHO, Word Health Organization). W drugim etapie przedłużono obserwację (CHEST-2), potwierdzając korzystny wpływ długotrwałego stosowania leku zarówno na poprawę funkcji czynnościowej pacjentów, jak i ich rokowanie.

Średnia zmiana dystansu w 6MWT po 12 tygodniach obserwacji w badaniu CHEST-2 (28 tygodni w badaniach CHEST-1 + CHEST-2) wynosiła 63 m w grupie otrzymującej uprzednio riociguat i $35 \mathrm{~m}$ w grupie otrzymującej uprzednio placebo. Ponadto wyjściowe prawdopodobieństwo przeżycia po roku wynosiło $97 \%$, po 2 latach - 94\%, a po 3 latach - 88\% [27]. Badania z zastosowaniem innych substancji czynnych, takich jak antagoniści receptora dla endoteliny, analogi prostacyklin czy inhibitory fosfodiesterazy 5 (PDE-5, phosphodiesterase type 5), prowadzono na zdecydowanie mniejszą skalę i tylko częściowo udało się spełnić punkty końcowe, na przykład w badaniu BENEFiT (Bosentan Effects in iNopErable Forms of chronlc Thromboembolic pulmonary hypertension) potwierdzano skuteczność bosentanu w zmniejszaniu naczyniowego oporu płucnego u chorych z nieoperowalnym bądź przetrwałym CTEPH, nie wykazano jednak istotnej poprawy w zakresie wydolności fizycznej w teście 6MWT w tej grupie pacjentów [25].

W 2015 roku rozpoczęto refundację leczenia riociguatem w Polsce.
Terapię riociguatem rozpoczyna się od dawki $1 \mathrm{mg}$ 3 razy/dobę, zwiększając ją o 0,5 mg co 14 dni (pod kontrolą ciśnienia systemowego). Eskalacja dawki riociguatu do maksymalnej (2,5 mg 3 ×/d.) trwa zazwyczaj około 8 tygodni. Głównym działaniem niepożądanym leku, a zarazem ograniczeniem zwiększania jego dawki, jest hipotensja i/lub objawy niedociśnienia (obniżenie skurczowego ciśnienia tętniczego < 95 mm Hg uniemożliwia dalsze zwiększanie dawki leku i jego aktualną dawkę należy zmniejszyć o 0,5 mg $3 \times /$ d.) [26]. Warto zwrócić uwage na kryteria włączenia do programu lekowego z zastosowaniem riociguatu. Poza pewnym rozpoznaniem CTEPH według wytycznych European Society of Cardiology/European Respiratory Society (ESC/ERS) [1] u pełnoletniego pacjenta powinno się wykonać badania obrazowe (arteriografię tętnic płucnych oraz jedno z trzech: rezonans magnetyczny, angiografia tomografii komputerowej, scyntygrafia płuc), pacjent musi być w II lub III klasie czynnościowej według WHO oraz spełnić specjalne kryteria hemodynamiczne, uzyskane podczas cewnikowania prawego serca, tj. mPAP większe lub równe 30 mm Hg i naczyniowy opór płucny większy lub równy 3,75 jednostki Wooda. Powyższe kryteria muszą być spełnione łącznie.

Obecnie riociguat jest jedynym dostępnym w Polsce i na świecie lekiem w nieoperacyjnym bądź przetrwałym CTEPH, w odniesieniu do którego udowodniono skuteczność zarówno w zakresie poprawy wydolności czynnościowej pacjentów, jak i parametrów hemodynamicznych (klasa zaleceń IB wg ESC/ERS) [1]. Ponadto, w świetle najnowszych wytycznych ESC/ERS 2015, riociguat jest lekiem zalecanym zarówno w monoterapii, jak i w terapii podwójnej z bosentanem w leczeniu PAH (w Polsce obecnie nie ma programu lekowego uwzględniającego riociguat w leczeniu PAH).

Nie ulega wątpliwości, że istnieje potrzeba prowadzenia dalszych badań długoterminowych z zastosowaniem riociguatu w celu poszukiwania możliwości farmakologicznej terapii skojarzonej w CTEPH. W zaleceniach ESC/ERS z 2015 roku podaje się I klasę zaleceń do stosowania riociguatu w połączeniu z bosentanem u pacjentów z PAH. W badaniu PATENT-1 (Pulmonary Arterial Hypertension Soluble Guanylate Cyclase-Stimulator Trial) (i jego kontynuacji PATENT-2) wykazano wydłużenie dystansu w 6MWT w grupie pacjentów z PAH (w porównaniu z placebo) przyjmujących riociguat w monoterapii lub w połączeniu $z$ antagonistą receptora endoteliny bądź analogiem prostacykliny [28, 29]. Przyszłe badania wykażą, czy podobne połączenie jest skuteczne również u osób z CTEPH. Należy jednak pamiętać, że z powodu wysokiego ryzyka ciężkiej hipotonii w żadnej grupie pacjentów nie powinno się stosować riociguatu w połączeniu z inhibitorami PDE-5 (np sildenafilem) lub donorami tlenku azotu (np. nikorandilem lub monoazotanem izosorbidu). 
Nowoczesna metoda przezskórnej angioplastyki balonowej tętnic płucnych (BPA, balloon pulmonary angioplasty) nabiera znaczenia jako alternatywa dla pewnej grupy chorych z CTEPH. W przypadku zmian umiejscowionych dystalnie, których szansa usunięcia chirurgicznego jest niewielka, metoda ta powinna być rozważona przed rozpoczęciem terapii farmakologicznej (w niektórych ośrodkach leczenie farmakologiczne i BPA są rozpoczynane równocześnie). Skuteczny zabieg, wykonany w doświadczonym w tego rodzaju procedurze ośrodku, wiąże się z poprawą parametrów hemodynamicznych oraz klasy czynnościowej [30, 31]. Polskie ośrodki, w których przeprowadza się BPA, przede wszystkim Klinika Krążenia Płucnego i Chorób Zakrzepowo-Zatorowych w Europejskim Centrum Zdrowia w Otwocku, ale również Klinika Chorób Serca i Naczyń Collegium Medicum Uniwersytetu Jagiellońskiego w Krakowie oraz Klinika Kardiologii i Chorób Wewnętrznych Warszawskiego Uniwersytetu Medycznego, należą do europejskiej czołówki ośrodków wykonujących te nowatorskie procedury.

\section{Wnioski}

Zaawansowane CTEPH to choroba o złym rokowaniu. Kluczowe wydaje się jej wykrycie we wczesnym stadium. Głównym elementem warunkującym rokowanie jest mPAP. Wykazano, że u chorych z mPAP powyżej $30 \mathrm{~mm} \mathrm{Hg}$ należy się liczyć z 50-procentową śmiertelnością w trakcie około 18-miesięcznej obserwacji [32]. Pacjentów, u których PAP było niższe, cechowało znaczące lepsze rokowanie (śmiertelność wynosiła 12\%). Zważywszy na fakt, że początkowy przebieg jest często bezobjawowy, niezwykle ważna pozostaje świadomość lekarza o możliwym rozwoju CTEPH, szczególnie u osób po przebytej ostrej PE. W Polsce są dostępne wszystkie formy leczenia CTEPH. Szybka diagnoza i odpowiednie leczenie przez wykwalifikowany zespół może znacznie poprawić rokowanie w tej chorobie.

\section{Konflikt interesów}

Autorzy deklarują, że uzyskiwali granty wyjazdowe/umowy sponsoringowe i honoraria wykładowe od firmy MSD.

\section{Abstract}

Chronic thromboembolic pulmonary hypertension (CTEPH) is a serious disease, usually caused by an incomplete recanalization of pulmonary vessels after acute pulmonary embolism. This leads to a significant remodeling of the remaining pulmonary vasculature and right ventricular failure. The prognosis depends on early diagnosis and proper treatment. Despite the availability of an effective method - pulmonary endarterectomy (PEA), more than one-third of patients is not eligible for this type of operation due to the localization and the character of lesions. In these patients, as well as in the persistent CTEPH after PEA, specific therapy with riociguat is recommended. Balloon pulmonary angioplasty, a new treatment method, can be considered in certain patients with inoperable CTEPH.

Key words: chronic thromboembolic pulmonary hypertension (CTEPH), right ventricular failure, pulmonary endarterectomy, balloon pulmonary angioplasty, riociguat

Folia Cardiologica 2016; 11, 5: 394-400

\section{Piśmiennictwo}

1. Galiè N., Humbert M., Vachiery J.L. i wsp. Guidelines for the diagnosis and treatment of pulmonary hypertension: the task force for the diagnosis and treatment of pulmonary hypertension of the European Society of Cardiology (ESC) and the European Respiratory Society (ERS), endorsed by the International Society of Heart and Lung Transplantation (ISHLT). Eur. Heart J. 2016; 37: 67-119.

2. Lang I.M., Pesavento R., Bonderman D., Yuan J.X. Risk factors and basic mechanisms of chronic thromboembolic pulmonary hypertension: a current understanding. Eur. Respir. J. 2013; 41: 462-468.

3. Dartevelle P., Fadel E., Mussot S. i wsp. Chronic thromboembolic pulmonary hypertension. Eur. Respir. J. 2004; 23: 637-648.

4. Jasiewicz M., Kamiński K. Rozwój nadciśnienia płucnego w przebiegu chorób lewej części serca oraz zmian zakrzepowo-zatorowych. Kardiol. Oparta na Faktach 2010; 2: 182-188.

5. Tapson V.F., Humbert M. Incidence and prevalence of chronic thromboembolic pulmonary hypertension: from acute to chronic pulmonary embolism. Proc. Am. Thorac. Soc. 2006; 3: 564-567.
6. Fedullo P.F., Auger W.R., Kerr K.M., Rubin L.J. Chronic thromboembolic pulmonary hypertension. N. Engl. J. Med. 2001; 345: 1465-1472.

7. Pengo V., Lensing A.W., Prins M.H. i wsp. Incidence of chronic thromboembolic pulmonary hypertension after pulmonary embolism. N. Engl. J. Med. 2004; 350: 2257-2264.

8. Egermayer P., Peacock A.J. Is pulmonary embolism a common cause of chronic pulmonary hypertension? Limitations of the embolic hypothesis. Eur. Respir. J. 2000; 15: 440-448.

9. Pepke-Zaba J., Delcroix M., Lang I. i wsp. Chronic thromboembolic pulmonary hypertension (CTEPH): results from an international prospective registry. Circulation 2011; 124: 1973-1981.

10. Moser K.M., Bloor C.M. Pulmonary vascular lesions occurring in patients with chronic major vessel thromboembolic pulmonary hypertension. Chest 1993; 103: 685-692.

11. Gali. N., Kim N.H. Pulmonary microvascular disease in chronic thromboembolic pulmonary hypertension. Proc. Am. Thorac. Soc. 2006; 3: 571-576. 
12. Klok F.A., Dzikowska-Diduch O., Kostrubiec M. i wsp. Derivation of a clinical prediction score for chronic thromboembolic pulmonary hypertension after acute pulmonary embolism. J. Thromb. Haemost. 2015; 14: 121-128.

13. Hoeper M.M., Mayer E., Simonneau G. Chronic thromboembolic pulmonary hypertension. Circulation 2006; 113: 2011-2020.

14. Riedel M., Stanek V., Widimsky J., Prerovsky I. Long-term follow up of patients with pulmonary thromboembolism. Late prognosis and evolution of hemodynamic and respiratory data. Chest 1982; 81: 151-158.

15. Lang I., Kerr K. Risk factors for chronic thromboembolic pulmonary hypertension. Proc. Am. Thorac. Soc. 2006; 3: 568-570.

16. Yang S., Yang Y., Zhai Z. i wsp. Incidence and risk factors of chronic thromboembolic pulmonary hypertension in patients after acute pulmonary embolism. J. Thorac. Dis. 2015; 7: 1927-1938.

17. Moser K.M., Braunwald N.S. Successful surgical intervention in severe chronic thromboembolic pulmonary hypertension. Chest 1973; 64: 29-35.

18. Mayer E., Jenkins D., Lindner J. i wsp. Surgical management and outcome of patients with chronic thromboembolic pulmonary hypertension: results from an international prospective registry. J. Thorac. Cardiovasc. Surg. 2011; 141: 702-710.

19. Jamieson S.W., Kapelanski D.P., Sakakibara N. i wsp. Pulmonary endarterectomy: experience and lessons learned in 1,500 cases. Ann. Thorac. Surg. 2003; 76: 1457-1462.

20. Delcroix M., Lang I., Pepke-Zaba J. i wsp. Long-term outcome of patients with chronic thromboembolic pulmonary hypertension results from an International Prospective Registry. Circulation 2016; 133: 859-871.

21. Hughes R.J., Jaïs X., Bonderman D. i wsp. The efficacy of bosentan in inoperable chronic thromboembolic pulmonary hypertension: a 1-year follow-up study. Eur. Respir. J. 2006; 28: 138-143.

22. Skoro-Sajer N., Bonderman D., Wiesbauer F. i wsp. Treprostinil for severe inoperable chronic thromboembolic pulmonary hypertension. Thromb. Haemost. 2007; 5: 483-489.
23. Reichenberger F., Voswinckel R., Enke B. i wsp. Long-term treatment with sildenafil in chronic thromboembolic pulmonary hypertension. Eur. Respir. J. 2007; 30: 922-927.

24. Ghofrani H.A., D’Armini A.M., Grimminger F., i wsp. Riociguat for the treatment of chronic thromboembolic pulmonary hypertension. N. Engl. J. Med. 2013; 369: 319-329.

25. Jaïs X., D'Armini A.M., Jansa P. i wsp. Bosentan for treatment of inoperable chronic thromboembolic pulmonary hypertension: BENEFiT (Bosentan Effects in iNopErable Forms of chronlcThromboembolic pulmonary hypertension), a randomized, placebo-controlled trial. J. Am. Coll. Cardiol. 2008; 52: 2127-2134.

26. Adempas (riociguat). Charakterystyka produktu leczniczego. Dostępne online: http://ec.europa.eu/health/documents/community-register/2014/20140327128191/anx_128191_pl.pdf. Data dostepu 8.06.2016 r.

27. Simonneau G., D’Armini A.M., Ghofrani H.A., i wsp. Riociguat for the treatment of chronic thromboembolic pulmonary hypertension: a longterm extension study (CHEST-2). Eur. Respir. J. 2015; 45: 1293-1302.

28. Ghofrani H.A., Galie N., Grimminger F. i wsp. Riociguat for the treatment of pulmonary arterial hypertension. N. Engl. J. Med. 2013; 369: 330-340.

29. Rubin L., Galie N., Grimminger F. i wsp. Riociguat for the treatment of pulmonary arterial hypertension (PAH): a long-term extension study (PATENT-2). Eur. Repsir. J. 2015; 45: 26-31.

30. Feinstein J.A., Goldhaber S.Z., Lock J.E. i wsp. Balloon pulmonary angioplasty for treatment of chronic thromboembolic pulmonary hypertension. Circulation 2001; 103: 10-13.

31. Kurzyna M., Darocha S., Koteja A. i wsp. Balloon pulmonary angioplasty for chronic thromboembolic pulmonary hypertension. Post. Kardiol. Interw. 2015; 11: 1-4.

32. Lewczuk J., Piszko P., Jagas J. i wsp. Prognostic factors in medically treated patients with chronic pulmonary embolism. Chest 2001; 119: 818-823. 